\title{
世界のガラス名品展
}

日本橋の白木屋で 8 月，世界のガラス名品展が開かれていた．有名なローマングラス，エジブトの古代ガ ラスを始め各国の珍しい作品が多数展示されていた.

これらのガラス製品を見ていると，古代の人々がガラスに托した夢が理解出来そうである。それはガラス というよりむしろ宝石を报う, 慎重さ, 真劒さが感じられる.特に多数展示されていた喆類の造型力には逞

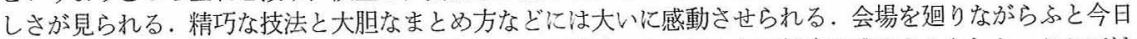
の理智的な機能偏重の造形観念と比㬵して如何にも人閒味のある温かさに魅力を感じさせられた。ここでは 多数の出品物の中から壖類を中心に造型的に興味ある作品の幾つかを紹介し，参考に供することにした。

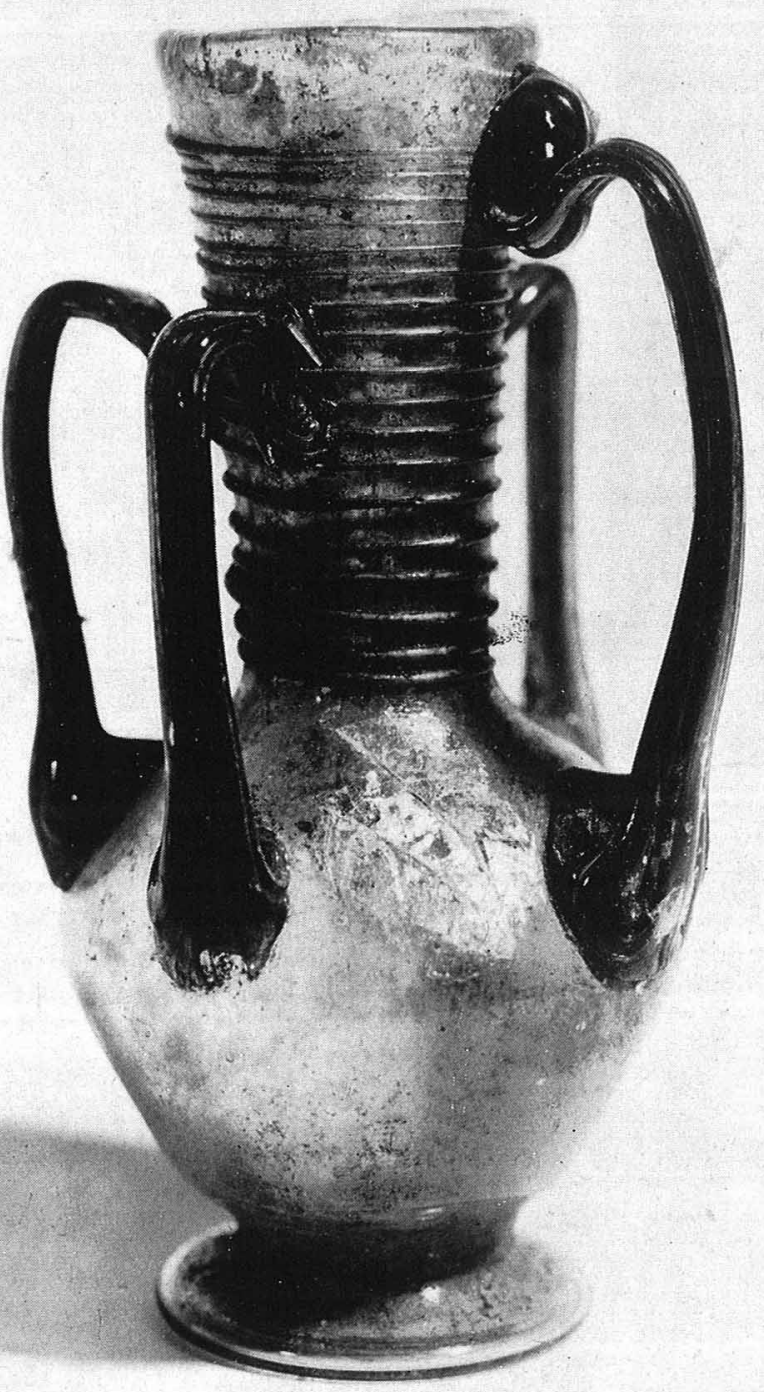



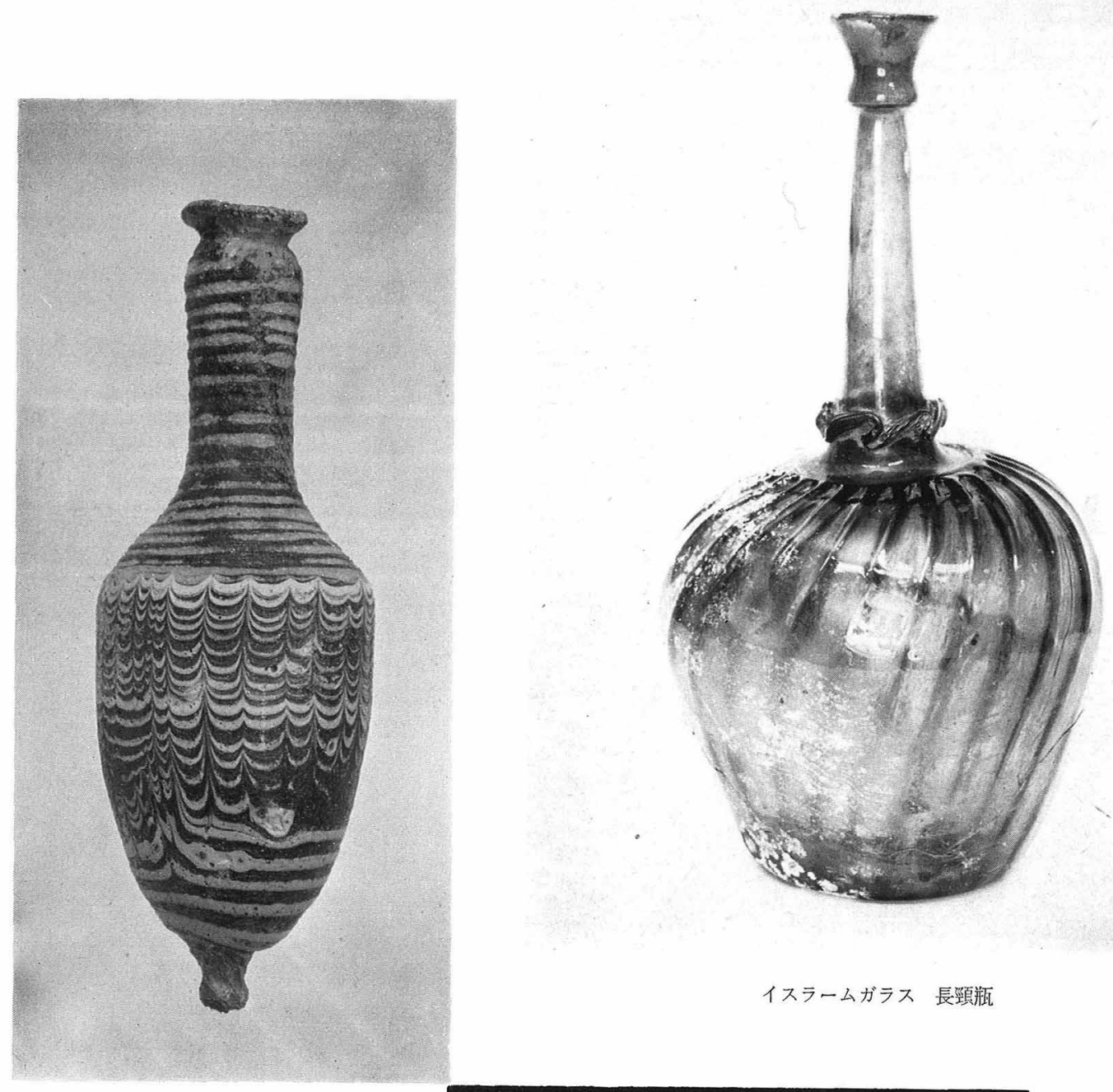

エジプト サンドコアグラス
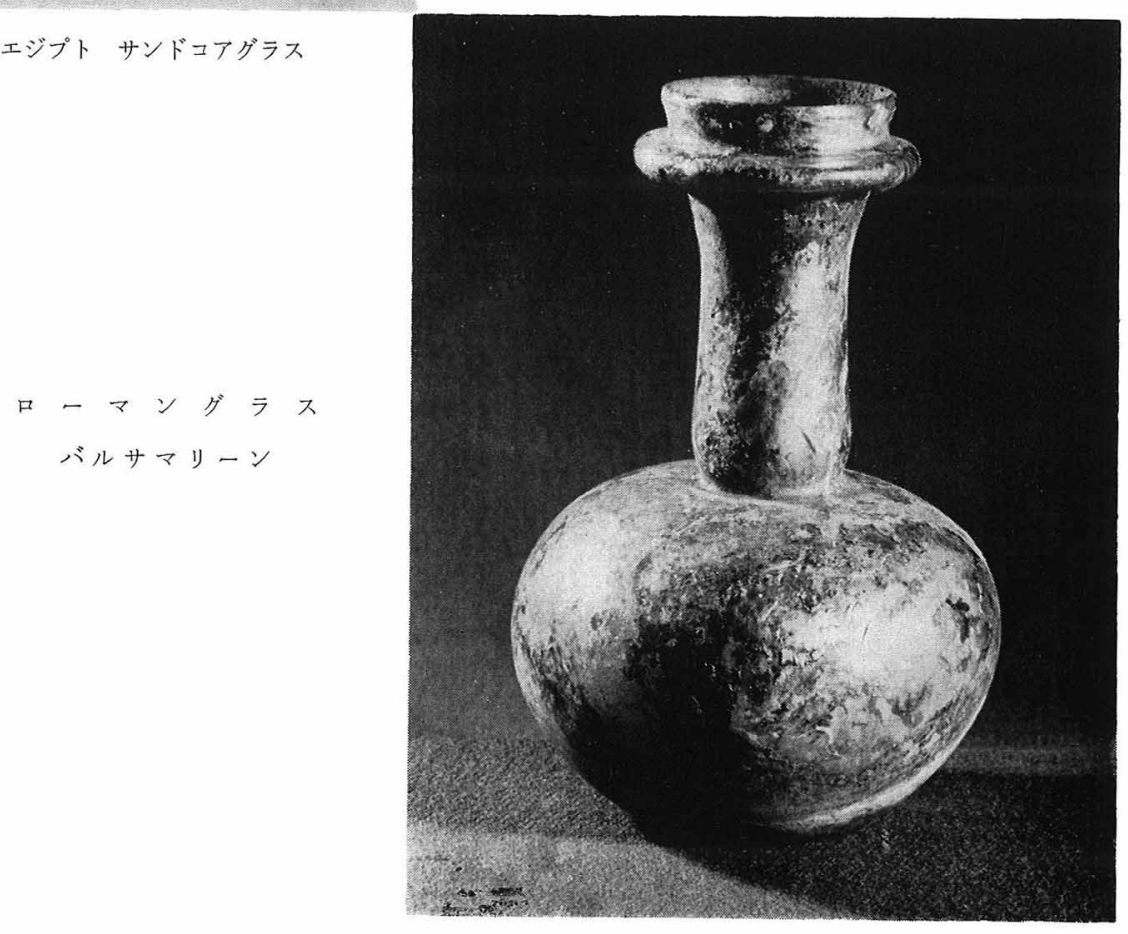


\section{エジプト サンドコアグラス}

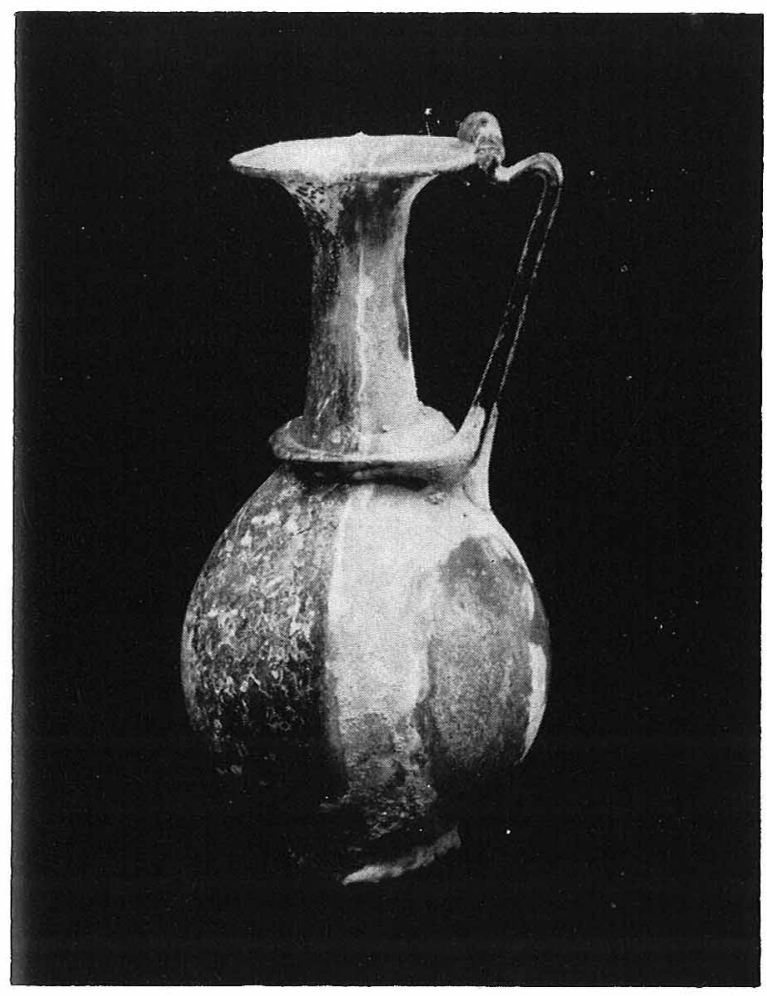

上ローマングラス 手附小瓶

在 ローマンラスグ 手附小瓶
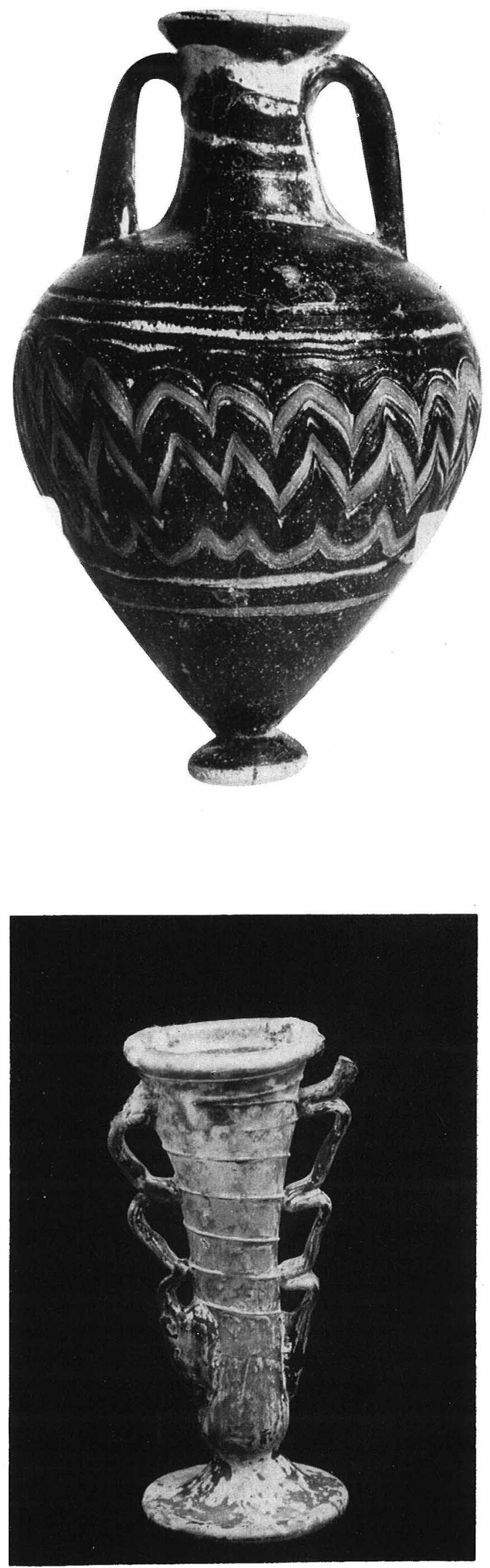
